\title{
Brexit and its possible implications for the UK economy and its regions: a Post-Keynesian perspective
}

\author{
John S.L. McCombie, ${ }^{1}$ Marta R.M. Spreafico ${ }^{2}$
}

\begin{abstract}
${ }^{1}$ Corresponding Author. Cambridge Centre for Economic and Public Policy, Department of Land Economy, University of Cambridge, 19 Silver Street, Cambridge, CB3 9EP, UK (e-mail: jslm2@cam.ac.uk)

${ }^{2}$ Institute of Economic Policy, Università Cattolica del Sacro Cuore, Milan, Italy (email: marta.spreafico@unicatt.it)
\end{abstract}

\begin{abstract}
This paper discusses the implications of Brexit for both the UK and its regions, as the latter depends on the former. We concentrate on the forecasts by Her Majesty's Treasury (HMT), the Cambridge Centre for Business Research and the Economists for Brexit. It is argued that the estimates of HMT of the loss of GDP are likely to be overstated, but, nevertheless, there will probably be a fall in output. Given this, the effect on the UK regions is analysed using the regional balance-of-payments constrained growth model. This suggests that Brexit will cause regional disparities to widen.
\end{abstract}

JEL classification: E17, E60, R11

Key words: Brexit, balance-of-payments constrained growth model, macroeconomic forecasts, North-South divide, UK regions 


\section{Introduction}

The result of the United Kingdom's referendum to leave the European Union (EU) in June 2016 has set in train possible far-reaching social and economic consequences for both the UK and its regions. On 29 March 2017, the UK government initiated the twoyear process by which the UK and the EU will negotiate the terms under which the UK will leave the EU, although this period may be extended. In many ways, these are unchartered waters, as there has never been a case before where a large country has left a customs union.

The referendum result was not withstanding the predictions of major economic forecasting models that agreed that the result of leaving the EU would lead to a substantial loss of income for the UK. These include the models of Her Majesty's Treasury (HMT) (2016a,b), the IMF (2016) and the OECD (2016). The potential loss of GDP in 2030, compared with the position if the UK had not left the EU, calculated by HMT (2016a) ranges from central estimates of 3.8 percent to 7.5 percent, depending upon the outcome of any new trade agreements negotiated with the EU. The loss is predicted to be substantially due to the reduction of the UK's trade with the EU. At present, UK exports to the EU account for 45 percent of the UK's total exports and for 12 percent of the UK's GDP.

In this paper, we discuss the possible implications of Brexit for the UK and, particularly, its regions. (The term Brexit is used for the actual leaving of the UK from the EU.) We begin by assessing some of the various approaches that have estimated the potential short-term and long-term losses arising from the UK's process of leaving the EU. This is done because the differing estimates from the various models at the national 
level inevitably have different implications for the regions. For example, on the one hand, if one accepts the results of, say, the Economists for Brexit (2016a), then Brexit is actually likely to have a positive impact on the UK economy and, hence, the regions. On the other hand, if one takes the forecasts of the majority of the other economic models, then the regional impact will be adverse to varying degrees.

We shall argue that the impact of Brexit on the UK, and hence its regions, may not be as damaging as some of the forecasts above suggest. We shall concentrate particularly on HMT (2016a, b) as this was most influential in the referendum debate. It also produces similar results to the IMF (2016) and OECD (2016) studies. However, this is hardly surprising as they are all based on the same underlying macroeconomic model ${ }^{1}$, and make approximately the same assumptions. Mention should also be made of Ottaviano et al. (2014) and Dhingra et al. (2017a) who, using a more sophisticated approach, find the losses allowing for dynamic effects to be similar to the upper end of HMT's estimates of the possible loss in the UK's GDP. The National Audit Office (2017) has undertaken a scrutiny of HMT (2016a, b), although without questioning its methodology. It notes that the Centre for Economic Performance (2016) criticised HMT for being somewhat cautious in its estimates.

However, it should be noted that there are dissenting views. The Keynesian forecasting model of the Centre for Business Research (CBR) (Gudgin et al. 2016a) concludes that there would be overall output losses, but they would be much less dramatic than those predicted by HMT. The most optimistic dissenting group are the

\footnotetext{
${ }^{1}$ This is the National Institute for Economic Research's NiGEM which is similar to a dynamic stochastic general equilibrium model.
} 
Economists for Brexit (2016a, b) ${ }^{2}$ who, using a different general equilibrium model, find that Brexit would lead to a gain in GDP of about four percent. (See, however, Sampson et al. 2016 and Winters 2017. Their critiques of the Economists for Brexit are discussed below.) There are also forecasts by other organisations, but for reasons of space we shall not consider them here. (See Emmerson, et al. (2016, Table 3.1, p.18) for a useful summary of all the major forecasts.)

We are particularly concerned with the regional dimension of both the referendum result and likely resulting economic consequences. The current regional imbalance in the UK, as reflected by the North-South divide, is one of largest in Europe (McCann, 2016). An important question, consequently, is whether or not Brexit will significantly worsen the North-South divide?

We discuss this by using a demand-oriented post-Keynesian approach to modelling the likely effect of Brexit on the regions, a perspective that has not been mentioned in any of the recent debates about the effects of Brexit. ${ }^{3}$ The regional balance-of-payments constrained growth model (Thirlwall, 1980; McCombie 1988) is an aggregate theoretical model that provides a conceptual framework for discussing the impact of Brexit. It is particularly relevant given the likelihood of an adverse demand shock resulting in the reduction of trade with the EU. It will be the fall of trade with the EU and, to a lesser extent, a decline in foreign direct investment (FDI), that will be fundamentally responsible for the loss of the UK's GDP. This approach analyses the impact of a fall in the growth of the regions' exports and imports on the growth of their output. This also leads potentially to a fall in productivity growth through the Verdoorn

\footnotetext{
${ }^{2}$ They are now retitled Economists for Free Trade (see https://www.economistsforfreetrade.com/).

${ }^{3}$ Furthermore, there is no mention of this approach in Capello and Nijkamp's (2010) handbook of regional growth theory and development.
} 
law, the relationship between the growth of productivity and output (Verdoorn 1949; McCombie et al. 2002). The law reflects the impact of increasing returns to scale, broadly determined. Unlike in many other cases where the neoclassical and postKeynesian models often come to different conclusions, here they are rather similar.

We begin with a review of a representative sample of the different approaches analysing the possible effects of Brexit, although for reasons of space this has to be limited.

\section{The Macroeconomic Forecasts of Brexit and their Implications for the UK}

\section{Economy}

In this section, we consider a number of possible outcomes of Brexit for the whole of the UK as a precursor to considering the possible regional impacts. We first consider the estimates of HMT (2016a, b) and then those of the CBR (Gudgin et al. 2017a, b) and, finally, the more optimistic predictions of the Economists for Brexit.

HMT (2016b) provides a short-term forecast of the immediate adverse impact on output over a two-year period after the vote to leave. HMT predicted that output would fall by 3 to 6 percent because of the assumption of the effects of the high degree of uncertainty caused by the impending Brexit. However, at the time of writing (October 2017), this is proving to be over-pessimistic. The actual growth of GDP in 2015 was 2.2 percent, in 2016 it was 1.8 percent and is forecast by the Office of Budget Responsibility (2017) to be 2.0 percent in $2017 .{ }^{4}$

\footnotetext{
${ }^{4}$ It could be argued that HMT's (2016b) starting point for its short-term forecast was the date of the implementation of Article 50 on $29^{\text {th }}$ March 2017, and the period from the vote to leave until this date was merely a period of wait and see. This argument is not compelling. HMT (2016b)
} 
Of greater importance are the various long-term estimates of the possible adverse effects on the UK's GDP. HMT's long-term model takes as its starting point the date of Brexit. As noted above, HMT's (2016a) estimates are expressed as the fall in GDP after a 15-year period, compared with the level of GDP that would have occurred if the UK had remained in the EU. The 15-year period is chosen as it is assumed that all the economic effects of Brexit would have worked themselves out by then. Three scenarios are considered in increasing order of disadvantage to the UK. They are (i) the UK joins the European Economic Area, (ii) the UK negotiates a Free Trade Agreement with the EU and (iii) the UK exits under the default position of the World Trade Organization's (WTO) "most favoured nation" rule. For expositional purposes, (following Gudgin et al. 2017a and the National Audit Office 2017), we shall concentrate on the worst-case scenario, the WTO outcome, although any of the other two outcomes could be chosen. It also enables us to compare Gudgin et al.'s results with those of HMT.

The methodological approach that HMT adopts is as follows. First, it calculates the likely decline in the UK's exports to the EU using a standard gravity trade model (HMT, 2016a, Annex A). This loss of trade is assumed to be the value of the extra UK trade that membership of the EU has conferred and which would no longer occur after Brexit. Secondly, it estimates the associated decline in UK's labour productivity resulting from this fall in trade. Thirdly, it repeats the exercise to calculate the loss in output due to the fall in FDI. Finally, the fall in productivity is treated as an adverse technological shock in the neoclassical Constant Elasticity of Substitution (CES) aggregate production function, with constant returns to scale, used in the NiGEM

throughout the document refers to the "immediate impact of the vote to leave". Moreover, the National Audit Office (2017, p.4) notes that the short-term forecast "covers the period from 2016 Q3 to 2018 Q2 immediately following a vote to leave". The delay in invoking Article 50 merely lengthened the period of uncertainty. 
macroeconomic model..$^{5}$ It is assumed that there is no significant import substitution or increased exports to other non EU markets. This, in addition to the fall in output from the lost trade, is used to forecast the possible falls in GDP, which can be considerable, ranging in the worst case from -3.4 percent to -9.5 percent, with a central estimate of -7.5 percent. (The best outcome for the UK has a central estimate of -3.8 percent.) It is assumed that the UK labour market is flexible, so that the fall in output does not lead to an increase in unemployment. The effects of changes in net migration are not considered in these exercises.

In estimating the gravity model, HMT (2016a, Annex A, Part 1) uses bilateral trade flows for goods for 200 countries, over the period 1948 to 2013. (A shorter period and fewer countries are used for international trade in services.) In order to quantify the effect of EU membership, a dummy variable is included, inter alia, when both trading countries are members of the EU. The estimated coefficient of the dummy variable shows that membership of the EU means that total exports are 76 percent higher, compared with WTO baseline. This is the average effect for all members of the EU and is assumed to apply to the UK. Consequently, it is assumed that Brexit, under the WTO terms, would lead to a decline in the UK's exports to the EU by 43 percent (i.e., 76/176 expressed as a percentage) which is equivalent to 24 percent of its total exports.

The next step in the argument is that this fall in trade is estimated to lead to a fall in the level of productivity of 6.25 percent, assuming a productivity-trade elasticity of 0.25. (HMT 2016a, Part 3. See also Crafts (2016) for a survey of studies that estimate

\footnotetext{
${ }^{5}$ There is a number of serious problems with the both the concept and use of aggregate production function and, hence, also for the NiGEM model. See Felipe and McCombie (2012, 2013) for detailed discussions. It is beyond the scope of this paper to discuss this important issue further.
} 
this elasticity.) The NIESR (Ebell and Warren 2016) using the same NiGEM model, but making no allowance for a decline in productivity, estimate the loss in GDP to be between 2.1 and 3.7 percent. If they allow for productivity effects, the estimates are, not surprisingly, similar to those of HMT. (See also Ebell, 2016.)

HMT also estimate that there would be a decline in FDI of about 20 percent, which leads to a further fall in productivity of 0.8 percent, assuming a productivity-FDI elasticity of 0.04 . On the basis of all these estimates, the worse-case scenario of HMT is a central estimate of decline in GDP of 7.5 percent. There is no allowance for the fact that Brexit may lead to a fall in the growth of productivity, so these estimates may be conservative.

How plausible are these estimates and the economic methodology of HMT? Let us, for the moment, assume that the HMT estimates of the benefits in terms of extra trade gained from the UK's membership of the EU are of the correct order of magnitude. Does this necessarily mean the costs of leaving the EU are equal to the negative value of this? To answer in the affirmative means that the costs of the UK leaving the EU are based on a symmetry assumption or, to put this another way, the lack of any path dependence or the absence of hysteresis. In other words, Brexit will lead to a loss of all those extra past gains in trade, output and productivity from EU membership. But how probable is this?

First, the assumption that all the productivity benefits from the increased trade will be lost is highly implausible. As Alfred Marshall (1890) pointed out long ago, in his famous Appendix $\mathrm{H}$, the gains from, for example, increasing returns are to a large extent irreversible when production contracts. Likewise, the productivity gains from the 
extra trade with the EU since the UKs accession in 1973 may be, to some extent, likewise irreversible.

Secondly, there are grounds for questioning the assumption that there will be a fall in UK's exports to the EU equivalent to the estimated increase from its EU membership. The decline in UK exports will be the result of the increased EU tariffs and the greater costs of compliance with EU trade regulations (i.e., the imposition of EU non-tariff barriers). While the benefits of the reduction of tariffs might have been large at the time of the UK's accession to the European Community (as it then was) in 1973, these have steadily fallen under trade deals brokered by GATT and the WTO. The average tariff facing the exports of non-EU members to the EU is now only about 3 to 5 percent, although this does conceal significant sectoral variations. For example, automobiles face a tariff of 10 percent. However, 31 percent of agricultural and 2 percent of nonagricultural products are imported duty free into the EU under the most favoured nation rule. As The Economist (2012) put it "exporters routinely have to absorb cost increases of this size caused by a surge in the oil price or a jump in the exchange rate". Indeed, the fall of sterling against the euro (as of October 2017) since the referendum of around 12 percent should offset this possible increase in exporters' prices.

Although HMT (2016a) correctly predict this depreciation of sterling in their short-term model, the effects are, ironically, not considered in their discussion about the long-term effects. However, Ebell and Warren (2016 p.133) undertake this exercise. They find that, because of the low price elasticities of demand for exports, only a very small increase in exports (what they term a "bounce-back") of between 1.6 and 2.4 percent of exports by 2030 occur from an effective exchange rate decline of 16 and 24 
percent, under the WTO scenario. This is compared with their estimate of the total decline of total UK exports of between approximately 21 and 29 percent.

This finding is instructive. First, rather than using the gravity model, suppose the question is posed another way - what will the likely loss of UK exports to the EU be because of the imposition of, say, a 3 to 5 percent average tariff? Estimates of export and import demand functions generally give the low values for the relevant price elasticities (e.g. the elasticities in the OBR 2013 and Gudgin et al. 2015 models are less than minus unity). This, together with the inferences drawn from Ebell and Warren's (2016) results, suggests that any loss in exports because of the higher relative prices due to the tariffs is likely to be small.

Secondly, a consequence of this is that it must logically be inferred that nearly all of the assumed fall in total exports, estimated by using the gravity model, must be due to the costs of the imposition of EU non-tariff barriers. But this is implausible. It is difficult accurately to measure non-tariff barriers in terms of "ad valorem tariff equivalents" (see the World Trade Organisation, 2012). HMT, nevertheless, contends that the empirical evidence suggests that non-tariff barriers between the EU and the US "increase trade costs by around 10\%, making them nearly three times larger than US tariffs" (HMT 2016a, Box 1.A p.35). However, it would be very misleading to apply this value to the UK, post Brexit. The Conformité Européenne rules have already been met by existing UK exporters to the EU and this will still be the case immediately after Brexit. The UK government is planning to incorporate a substantial proportion of EU regulations into UK law. Moreover, about 80 percent of the agreed EU standards for manufactured goods are voluntary. They have been initiated by EU industry outside the EU framework to promote competition. However, this is not to say that non-tariff 
barriers will not impose any extra costs on UK exporters. Yet PwC (2016, p. 24) estimate the effect of non-tariff barriers would only be a tariff equivalent of 1.4 percent on exports. Using price elasticities of minus unity, the fall in EU exports and imports due to the increase in tariffs and price-equivalent non-tariffs are likely to be around 5 to 10 percent respectively. This excludes the effect of a depreciation in sterling. Whatever the eventual outcome of the negotiations triggered by Article 50, UK exporters are unlikely to find themselves facing a situation where trade conditions and barriers are the same as they were before the UK's accession in 1973. Nevertheless, there is great uncertainty around the costs of a "chaotic" or "hard" Brexit. As The UK in a Changing Europe (2017) have pointed out, the cost of a "no deal" may be higher than usually thought.

According to HMT (2016a) the benefits of trade for firms include economies of scale, increased competition and the improved allocation of capital (HMT, 2016a, Box A, p.14). These sit uncomfortably with the assumption of a constant returns to scale aggregate production function and profit maximisation by firms in competitive markets, as in the NiGEM model. (See also footnote 5.)

We turn next to the CBR model which is an econometrically estimated Keynesian macroeconomic forecasting model, using UK time-series data (Gudgin et al. 2015, 2017a). A number of assumptions are made in the model to generate estimates of the possible impact of Brexit. Gudgin et al. (2017a) find that up until 2020, the lower exchange rate offsets the adverse effects of uncertainty. By 2025, with an assumed loss of trade with the EU of 20 percent leads to a decline of 2 percent of GDP, compared with the position if the UK had remained in the EU. 
Productivity is only very marginally lower because of the decline in migration, as the migrants generally take lower paid jobs, but it is not clear that this is necessarily true of EU migrants. While immigration was, in some areas, a major issue in the Brexit debate, the increase in the number of EU immigrants tripling from 0.9 million to 3.3 million had little if any adverse impact on wages or job prospects of UK nationals. The fall in wages subsequent to 2008 was due to the financial crisis, not immigration. Many of the EU immigrants are better educated and have greater skills than the UK born nationals ( $44 \%$ have been educated at the level of higher education compared with $23 \%$ of UK born nationals). Moreover, the level of employment is not a fixed fund. New immigrants generate greater demand and, consequently, greater output and have positive effects on the level of productivity (Dhingra et al. 2017a, pp. 30-32). Moreover, there seems to be little evidence that immigration has increased income inequality. There is also a spatial element to any reduction in the level of migration with Brexit. Migrants play a particularly important role in supporting the local economy, such as in London. Even regions whose export sector does not depend heavily on the EU may be adversely affected economically if there is no freedom of movement and they rely on labour from the EU. There is also the unquantifiable psychological impact on currently resident EU nationals with the move towards Brexit. ${ }^{6}$

Gudgin et al. (2017a) examine the trade performance of the UK over the postwar period. It is found that UK exports to the EU had a trend rate of GDP growth of 6 percent since 1950, and there was no acceleration subsequent to the UK's accession in 1973. They argue that there is no compelling reason to assume that the UK's growth rate of GDP (and productivity) would have slowed down had it not joined the EC. The

\footnotetext{
${ }^{6} \mathrm{We}$ are grateful to a referee for these points.
} 
annual growth of the UK exports to the rest of the world was just over 3 percent prior to 1976, but only 1.5 percent per annum from 1976 to 1989 . This suggests, according to Gudgin et al. (2017a), that, contrary to HMT, there was substantial trade diversion (from, for example, trade with New Zealand).

Moreover, the exports to the EU as a proportion of the UK's total have been slowly declining from nearly 50 percent in 2005 to 42 percent in 2015 . On current trends, the share would have fallen to 29 percent by 2035 even if the UK had remained in the EU (Protts, 2016). (Slater, 2016, finds similar results.)

Gudgin et al. (2017a) using their Keynesian forecasting model, together with their own assumptions, find that the loss in GDP is some 2 percent in 2025. Using HMT's assumptions, their forecasting model gives a loss of 5 percent in 2025 compared with Treasury's 7 percent for 2030. This suggests that the different assumptions made about the degree of the fall in trade with the EU caused by Brexit are crucial.

In a follow-up paper, Gudgin et al. (2017b) present a detailed reassessment of the gravity model results, per se, of HMT (2016b), IMF (2016) and OECD (2016). Gudgin et al. (2017b) estimate a number of different specifications of the gravity model, under what they assume to be more plausible assumptions. They find that the UK benefits from being a member to be less than that of the EU average member, on which HMT's calculations are based. They further conclude that their preferred specification would give a loss in goods exports to the EU of 23 percent (p.7). They also found that, using more sophisticated estimation techniques, this loss (and conversely the benefits of being a member of the EU) has declined over time. They are also sceptical of HMT's effect of the reduction of FDI due to Brexit. This is because the data for FDI used by HMT are 
for financial flows, much of which is used for mergers and acquisitions, rather than for physical investment. It is the latter which is important for increasing GDP (p.8).

The results of estimating gravity models are extremely sensitive to the exact specification of the model and estimation procedures used (Glick et al. 2015). Consequently, Gudgin et al. (2017b) are cautious about drawing any firm policy conclusions about Brexit from this approach. Burrage (2017, Appendix 1) considers three other studies that HMT (2016, p.38) cites in support of their own gravity model's results. He considers that HMT's discussion of the results plays down the serious caveats expressed in these studies. (See also Burrage (2016) for a critique of HMT's estimates.)

The most optimistic forecast of the impact of Brexit is that of the Economists for Brexit (2016a) using a model developed by Minford (Minford, et al. 2015). They anticipate a gain of 4 percent of GDP, even if the UK leaves under the WTO option. This approach is quintessentially neoclassical. First, the UK consumers will benefit from not having to pay tariffs on their imports, which are above the world free-trade price. Tariffs also cause production distortions leading to overproduction of the protected industries, and consequently, to efficiency losses.

Even under the WTO scenario or unilateral free trade (which the Economists for Brexit (2016a) argue is optimal), the UK, as a small country by world output standards, will, in effect, face a perfectly elastic demand for its exports when trading on world markets. This is essentially the operation of the law of one price, where identical exports face the same world prices in perfectly competitive world markets. This is usually considered to be applicable to homogeneous goods, but the Economists for 
Brexit consider that all exports are bundles of differing characteristics, from which consumers can pick and choose.

Consequently, it is argued that after Brexit, there will be no loss of UK exports as exporters can simply sell in other overseas markets. Thus, there will be no output losses from reduced access to the EU market. Brexit will lead to productivity gains with the improved allocation of resources, even if it means the eventual extinction of UK manufacturing, with total reliance on services where they consider UK's comparative advantage lies. The gravity models of HMT, and others, are dismissed as subject to selection bias and their parameters are likely radically to change when a shock such as Brexit occurs. Sampson et al. (2016) criticise this analysis, as their own model suggests that removing import tariffs only increases GDP by 0.3 percent. They also argue that "Minford's model is hard-wired to predict that EU membership is only trade diverting and Brexit would lead to higher trade" (p.6). They then cite the gravity model studies cited above (and which the Economists for Brexit (2016b) heavily criticise) in support of their contention that membership of EU is trade creating and not diverting. But, as we have seen, empirically, relative prices play only a minor role in trade. So, the law of one price clearly does not hold. Winters (2017) also makes the same point about the existence of product differentiation and defends the use of the gravity model. He argues that according to Minford's own model "gaining $4 \%$ requires more integration with Europe than the UK has at present".

To conclude, even though the gravity model may overstate the trade costs of the UK leaving the EU, it still shows that it may not be an easy matter for UK exporters simply to switch to other overseas markets. The forecast of an increase in four percent of GDP by the Economists for Brexit looks as over-optimistic as HMT's forecast is 
over-pessimistic. $\mathrm{T}$ he most important issue is whether or not all the gains from the UK's Accession in 1973 will be lost on Brexit. Given the low UK price elasticities for exports and imports noted above and the likely price rises due to tariffs and non-tariff barrier equivalents, the loss of trade is likely to be much less than that predicted by HMT.

We next turn to the spatial implications of Brexit.

\section{Spatial Implications of the Outcome of the Referendum}

The result of the referendum was surprising, with 70 percent of those surveyed on the day expecting the remain vote to win (Ashcroft, 2016). This is notwithstanding that there had been growing disenchantment with the EU since the mid-1990s, as reflected in various opinion polls (Swales, 2016, p. 5).

The reasons behind the outcome of the voting are many and varied. Research on the voting patterns suggests that those voting for Brexit were older, on lower incomes, had less education and were more likely to live in social housing (Ashcroft, 2016). A survey of the reasons of those who voted to leave found that the most important issue was one of national sovereignty, followed by immigration. While the level of immigration in the Local Authority areas did not seem to have any statistical significance in explaining the leave share, the recent increase in immigration over the last decade was positively correlated with the leave vote. Only 6 percent of the leave voters said that the main reason they voted that way was that they believed the UK economy would be better off outside the EU. Clearly, the possible effect of Brexit on the economy was not a major factor in deciding the referendum outcome. 
However, Dorling (2016) points out that most people who voted leave live in the South of England and argues that the declining health and living standards in the northern regions was not the result of immigration, "but ever growing inequality and public spending cuts that accompanied austerity". What came out of the various analyses of the referendum vote was that place matters. "It's the shape of [the UK's] long lasting and deeply entrenched geographical inequality that drove differences in voting patterns" (Resolution Foundation, 2016). Goodwin and Heath (2016) found that both the less well-educated and those with A-levels and university degrees were proportionately more likely to vote for Brexit in the less-skilled areas compared with areas with higher-skills. They explain this result in terms of the disillusioned relatively well-educated workers lacking the opportunity to take good jobs in the areas where they lived and feeling marginalised in society. They concluded that "support for Brexit was strongest where a large percentage of the population did not have any qualifications and were ill-equipped to thrive amid a post-industrial and increasingly competitive economy that favours those with skills and is operating in the broader context of globalisation" (2016a, p.5).

Los et al. (2017) review a number of other studies that consider this question and which come to much the same conclusion. Furthermore, using the interregional extension to the World Input-Output Database, Los et al. (2017) present statistical evidence of what might be termed the "regional Brexit paradox". This is that on a number of indicators such as, for example, the share of a region's GDP exported to the EU, those voting to leave were proportionally greater in those regions that are more closely interlinked with the EU and likely to be hardest hit. But, nevertheless, these 
were the ones that the benefits of globalisation had largely passed by as reflected in the deindustrialisation in these regions.

Dhingra et al. (2017b), however, find that cities in London and the South East are likely to experience larger adverse impacts of Brexit than the rest of the country. They attribute this to other studies underestimating the importance of non-tariff barriers and not taking into account the willingness to substitute domestic goods for imports as trade costs rise. Moreover, these cities specialise in the knowledge-based sectors such as business and the financial sectors, which are likely to be the hardest hit by Brexit. Thus, those areas which voted to remain were, in fact, according to Dhingra et al. (2017b), those that would be hardest hit by Brexit. But they argue that these dynamic cities are likely to be the best placed to respond the negative shock of Brexit.

The outcome of the referendum reflects both the social and economic divisions in the UK. In this sense, the results of the voting stem from a failure of post-war economic policies to reduce regional disparities and the North-South divide. However, the vote to leave the EU may actually worsen the regional disparities in the future to some degree.

\section{The Economic Implications of Brexit for the UK Regions}

What are the likely output implications of Brexit for the UK regions? The predictions of severity of the impact will depend upon the plausibility of the estimates of the various studies discussed above.

The UK has a larger degree of regional inequality than any other major OECD country (McCann, 2016). The UK's coefficient of variation in regional per capita income at the NUTS-2 level is double that of any of the EU's other five largest 
economies (Bell, 2017, p. S101). Los et al. (2017) and McCann (2016) describe the divergence of the economic performance of London and its hinterland and the remainder of the UK regions.

Thus, even if the short-term and the long-term consequences of Brexit have been overestimated by HMT, inter alia, Brexit could have serious adverse effects for the UK regions and cities, exacerbating the North-South divide (Springford, 2015; Sheffield Political Economy Research Institute (SPERI) 2016). There is also a much greater disparity on dependence on the EU at the city level. According to the Centre for Cities (2017, Figure 9, p. 19), Exeter and Plymouth are the most heavily dependent on the EU for their exports, with 77 percent and 68 percent going to the EU respectively. At the other extreme is Hull and Derby, with only 29 percent and 25 percent respectively. Also the value of total exports per employee varies considerably between cities, ranging from $£ 40,650$ (Sunderland) to York $(£ 3,710)$. Thus, the implication is that the impact of Brexit will vary spatially to a great extent and it risks worsening the North-South divide (Springford, 2015; SPERI 2016, Los et al. 2017).

A problem is that the potential adverse effect of Brexit is not just a question of the proportion of exports of a region or city that goes to the EU. It also involves their supply chains and the extent to which these are located in other regions and cities (Immarino and McCann 2013 and McCann 2016, chapter 4). There are important industries, such motor vehicles and aerospace, that have complex supply chains of intermediate inputs that criss-cross the EU border (KPMG, 2014; HMT, 2016a, Box 1.c, p.40). After Brexit, these industries will have to face new EU tariffs and compliance procedures on multiple occasions, even though they may be compliant with existing ones. The export of services to the EU is important and is also likely to have a spatial impact. The impact 
on the financial services sector, if passporting fails to be granted by the EU, will largely hit Central London. However, it should be noted that while there are 400,000 employees in the financial services in London, there are 85,000 and 98,000 employees in this sector in Scotland and the North West, respectively. 40 percent of J.P. Morgan's staff are based outside London (HMT 2016a, Box 1.D; p.42). Thus, the impact on the financial services is likely to be more regionally widespread than is commonly thought.

While the regional automatic economic stabilizers will come into play after Brexit, much will also depend upon the degree of government support for the hardest hit regions and cities. The degree to which the government makes up for the loss in EU regional funding will be a further important factor. Norton (2017) argues that one benefit of Brexit is that it will give the UK government greater discretion in which areas regional aid is given. Bachtler et al. (2016) and Bell (2017) discuss the possible options for regional policies post Brexit.

An important consequence of the fall in regional demand caused by Brexit is that it will have a different impact compared with other recessions in the post-war period. This is because economic recovery has to be export-led. Merely increasing demand in the regions will lead to interregional balance-of-trade problems, and consequently can only have limited success. We next illustrate this argument using the regional balanceof-payment constrained growth model.

\section{Post-Keynesian Regional Growth Theory and the Impact of Brexit}

In this section, we analyse the effect of Brexit using a demand-oriented growth model. This approach has its origins in an influential paper by Kaldor (1970). Kaldor's verbal 
model was formalised by Dixon and Thirlwall (1975) and forms the basis of the cumulative causation model of growth. The key assumption is that the growth of a region's output is primarily dependent on the growth of its exports, working through the dynamic Harrod-trade foreign trade multiplier and, more generally, the Hicks supermultiplier. As such, the model represents a formalisation and extension of the traditional export-base model of regional activity (North 1955) within a macroeconomic framework. See, for example, Rowthorn (2010, Appendix 1) for an application to the UK.

The cumulative causation nature of growth is given by the Verdoorn law (McCombie et al. 2002). In its simplest form, this is a relationship between the growth of manufacturing productivity and output. A faster growth of the output causes a faster growth of the productivity, through induced technical change and both dynamic and static returns to scale. (See, for example, Angeriz et al. (2008)). In the original Dixon and Thirlwall (1975) model, the growth of nominal wages is the same across regions, being set in national markets. The model predicts either convergence to an equilibrium growth rate or explosive growth depending upon the parameters of the model. However, there are two problems with this approach. First, empirical evidence suggested that firms competed largely through non-price factors, i.e., trying to shift the demand curve for their firm's product outwards, rather than moving down the demand curve (McCombie and Thirlwall, 1994, Chapter 4).

Secondly, there is nothing in the model to prevent the growth of imports permanently exceeding the growth of exports, which has to be financed by an increasing growth of net financial flows. This led to the development of the balance-of-payments constrained growth model, which is equally applicable to the national or regional level 
(Thirlwall and Dixon, 1979). As Thirlwall (1980) comments "Regional problems are 'balance-of-payments' problems”. The model, in its simplest form, is as follows. The growth rates of exports and imports are given by the following export and import demand functions expressed in growth rates.

$$
x=\varepsilon Z+\psi\left(p_{R}-p_{Z}-e\right)
$$

where $x$ is the growth of exports, $\varepsilon$ is the income elasticity of demand for the region's exports, $z$ is the weighted growth of the region's export markets, $\psi(<1)$ is the price elasticity of demand for the region's exports, $p_{R}$ is the growth of the price of the region's exports, $p_{Z}$ is the growth of prices of the region's imports and $e$ is the rate of change of the exchange rate. We are assuming here, for simplicity, that the region trades only with overseas markets.

The import demand function is given by:

$$
m=\pi y+\eta\left(p_{z}+e-p_{R}\right)
$$

with the same notation as above and additionally where $m$ is the growth of imports, $\pi$ is the income elasticity of demand, and $\eta(<0)$ is the price elasticity of demand for imports. The balance-of-payments accounting identity is given by:

$$
\rho x+(1-\rho) f \equiv m+p_{Z}+e-p_{R}
$$


where $f$ is the growth of net capital inflows and $\rho$ is the share of exports in total receipts. The constraint arises because, as we have noted, in the long run, a region cannot finance a growing trade deficit indefinitely by the growth of extra-regional borrowing. Consequently, we assume that the growth of exports and imports must be equal in the long run. The importance of the regional balance of payments has often been overlooked because there cannot be a regional currency crisis. As Dow (1986) has pointed out, the fact that with a national banking system, a region's bank loans do not have to be matched by deposits in the region may give the impression that financial flows are automatically accommodating. But they are not. As output and employment in the region falls, any attempt to maintain private consumption necessitates borrowing, but this will be increasingly limited by the decline in the value of regional collateral and the increasing ratio of regional debt to regional output. Credit rationing will occur or the interest rate for borrowing will increase or, more likely, both. Thus, a fall in exports will set in train a negative multiplier effect as regional consumption falls. The rate of investment in the region is also likely to decline. Moreover, there are already regional fiscal transfers from the more prosperous areas of England subsidising not only Northern Ireland, Scotland and Wales, but also the less prosperous parts of the UK (Oxford Economics 2008; McCann 2016, Chapter 5, section 5.3.2)). Apart from the limited operation of the automatic fiscal stabilisers, it is unlikely that there will be any significant increase in the rate of growth of interregional government transfers to the hardest hit regions.

If we assume that there are no net capital flows, then equation (3) becomes the constraint expressed as: 


$$
x=m+p_{Z}+e-p_{R}
$$

Substituting equations (1) and (2) into (4), we obtain an equation for the regional balance-of-payments constrained growth rate:

$$
y_{B P}=\frac{1}{\pi}\left(\varepsilon Z+(1+\eta+\psi)\left(p_{R}-p_{Z}-e\right)\right)
$$

Empirically, the price term is found to be quantitatively unimportant as the growth of relative prices do not diverge greatly in the long run, i.e. $\left(p_{R}-p_{Z}-e\right) \approx 0$. This leads to "Thirlwall's law", namely:

$$
y_{B P}=\frac{x}{\pi}=\frac{\varepsilon z}{\pi}
$$

The effect of the growth of relative prices can also be negligible because the Marshall-Lerner conditions are barely met $(\eta+\psi \approx-1)$.

Differences in regional growth rates are primarily a result of differences in the ratio of the income elasticities of demand, which capture differences in non-price competiveness, including the structure of production. A region where the structure of production is specialising on, say, steel is likely to have an income elasticity of demand for exports that is lower than a region specialising in hi-tech goods.

A problem with Thirlwall' $\mathrm{s}$ law is that as Tiebout (1956) raised with reference to the export-base model, there is no role for the growth in the non-tradable sector to affect the regional growth rate. 
The answer to this conundrum is that equation (6) should be regarded as a simply a locus of the growth rates of the region, where the region is in balance-of-payments equilibrium for any given $z$. However, there is an additional equation for the growth of regional demand $\left(y_{D}\right)$ that is derived from the Keynesian aggregate demand function. This is given by:

$$
y_{D}=\alpha a+\beta x=\alpha a+\beta \varepsilon z
$$

where $a$ is the growth of "autonomous" expenditure and $\alpha$ and $\beta$ are the dynamic multipliers. Equation (7) does not take into account whether or not the balance of payments is in equilibrium (see McCombie, 1993, for the full model). Consequently, the growth of the region, consistent with its trade being balanced is given by:

$$
y_{B P}=\frac{x}{\pi}=y_{D}=\alpha a+\beta \varepsilon Z
$$

If the growth of exports falls, say, with Brexit, the region will start to run a balance-of-payments deficit. As this cannot persist for the reasons set out above, the growth of the "autonomous" expenditures (which, in this sense, are not really autonomous) will decline. For example, as mentioned above, negative wealth effects will reduce the growth of consumption and regional investment will be curtailed. This brings the growth of regional aggregate demand back into line with the now lower growth of regional output that is consistent with the trade being in balance.

We are now in a position to consider the regional impact of Brexit. First we consider the immediate, or short-run impact, of Brexit. Consider first the effect of the 
imposition of a tariff on exports. The demand for a region's exports in logarithmic form is given by:

$\ln X=\ln C_{0}+\theta \varepsilon_{E U} \ln Z_{E U}+(1-\theta) \varepsilon_{R o W} \ln Z_{R o W}+\theta \psi \ln \left(\frac{P_{R}(1+\mu)}{P_{E U} E_{E U}}\right)+(1-\theta) \psi \ln \left(\frac{P_{R}}{P_{R O W} E_{R O W}}\right)$

with the same notation as before, but where the upper case denotes a level. $E_{E U}$ and $E_{R O W}$ are the region's exchange rate with the EU and the Rest of the World respectively. $\theta$ is the share of the UK's exports going to the EU and $\mu$ is the percentage value of the EU tariff imposed after Brexit. This last has an effect of reducing the level of the region's exports to the EU, and hence output, as $\partial \ln X / \partial \ln (1+\mu)=\theta \psi<0$. $\theta$ will also decline with the tariff increase. It follows that for a particular region, the greater the share of its exports that go to the EU, the greater will be its decline in output. Furthermore, the greater the ratio of the region's exports to its output, for a given share of exports to the EU, the greater also will be the fall. The position with respect to imports from the EU is the mirror image of the above, although given the structure of regional demand, the share of EU imports in output and total imports is unlikely to vary across regions as much as exports.

Nevertheless, given the low empirical estimates of the price elasticities discussed above, the fall in exports and imports are not likely to be substantial. The fall in exports may also be offset by a depreciation of the exchange rate by an equivalent amount to the increase in the tariff, as has already occurred at the time of writing. Under these circumstances, the imposition of the tariff would again have little, or no effect, on the region's exports to the EU. Furthermore, because of the multiplicative nature of the export demand function, the imposition of a tariff will not affect the growth of exports, 
or imports, unless the tariff continuously increases over time. The fall in the exchange rate will further increase the price of imports in terms of the domestic currency, sterling, which ceteris paribus, will lead to a fall the real wage. If there is real wage resistance, these may lead to an increase in domestic prices eventually offsetting the depreciation. The Economists for Brexit, as we have seen, advocate unilaterally cutting all existing tariffs of imports into the UK, which would counteract this to some extent.

The second result of Brexit is the imposition of non-price trade barriers, which is interpreted here as a fall in the income elasticities of demand for exports and imports. The non-price barriers include the effect of the disruption of international supply chains. It is noticeable that the gravity models estimated by HMT (2016) and Gudgin et al. (2017b) do not include a relative price term.

The fall in the income elasticity of demand for exports will cause a fall in the region's exports. As with the imposition of a tariff, a greater fall in output, ceteris paribus, will occur for two reasons. The first is when there is a greater share of exports to the EU in the region's total exports. The second is when, for any share of exports to the EU in the region's total exports, there is a greater share of exports in total output. The greatest effect is when both these occur.

If there were no increase in the non-tariff barriers for imports, and therefore no initial fall in imports, the total fall in regional output would be greater than just that of the fall in exports. The reason is that for balance-of-payments equilibrium, imports would have to fall to match the decline in exports. Consequently, imports fall through the import demand function as income, or equivalently, output declines. Through the workings of the Hicks super-multiplier (McCombie and Thirlwall, 1994, Chapter 6) this requires income to fall by more than the decrease in exports. However, the imposition of 
non-price tariffs causes imports to fall in addition to that caused by the decline in income. Consequently, under these circumstances the fall in regional income will be commensurately smaller than under the first scenario.

Turning to the effect on long-run growth, because of the results from the gravity model that show being a member of the EU increases the trade between the UK and the EU, ceteris paribus, we assume that $\varepsilon_{E U}>\varepsilon_{R O W}$ and $\pi_{E U}>\pi_{R O W}$. For expositional ease, we assume that $z_{E U}$ is equal to $z_{R O W}$, which we denote by $z$. But this is not essential to the argument. Brexit and the increase in non-price tariffs results in an immediate one-off proportionate fall in $\varepsilon_{E U}$ and $\pi_{E U}$. The balance-of-payments growth of the region prior to Brexit is given by:

$$
y_{B P}=\frac{\theta \varepsilon_{E U} Z_{E U}+(1-\theta) \varepsilon_{R O W} Z_{R O W}}{\omega \pi_{E U}+(1-\omega) \varepsilon_{R O W}}=\frac{\bar{\varepsilon}}{\bar{\pi}} Z
$$

A bar across the notation for the elasticities of demand indicates that they are the aggregate values. We assume that the region under consideration is more dependent on the EU for its exports than its imports, and so $\theta>\omega$. In other words, the region specialises more than the UK (or the average region) in exporting to the EU.

After Brexit, the growth of the region is given by:

$$
y_{B P}^{\prime}=\frac{\theta^{\prime} \varepsilon_{E U}^{\prime} z_{E U}+\left(1-\theta^{\prime}\right) \varepsilon_{R O W} z_{R O W}}{\omega^{\prime} \pi_{E U}^{\prime}+\left(1-\omega^{\prime}\right) \pi_{R O W}}=\frac{\bar{\varepsilon}^{\prime}}{\bar{\pi}^{\prime}} z
$$

where the prime denotes a post-Brexit different value. $\varepsilon_{E U}^{\prime}, \pi_{E U}^{\prime}, \theta^{\prime}$ and $\omega^{\prime}$ are smaller than the pre-Brexit values. 
The aggregate income elasticity of exports has fallen more than the aggregate elasticity of imports, because of the greater share of EU exports compared with EU imports and the fall in both $\varepsilon_{E U}$ and $\pi_{E U}$. Thus, comparing the equilibrium growth rates we have:

$$
y_{B P}=\frac{\bar{\varepsilon}}{\bar{\pi}} z>y_{B P}^{\prime}=\frac{\bar{\varepsilon}^{\prime}}{\bar{\pi}^{\prime}} z
$$

This change in growth rates is shown in Figure 1 . The line $B P_{0}$ is the initial locus of the region's balance-of-payments equilibrium growth rate and is given by the equation $y_{B P}=\bar{\varepsilon} z / \bar{\pi}$. The line $A_{0} A_{0}$ is the region's growth of aggregate demand, given by equation (8). The initial output growth of the region consistent with its balance of payments being in equilibrium is consequently given by $y$ at the point $a$ where the growth of its export markets is given by $z_{0}$. With Brexit, $\bar{\varepsilon} / \bar{\pi}$ falls to $\bar{\varepsilon}^{\prime} / \bar{\pi}^{\prime}$ for the reasons set out above. This causes the balance-of-payments equilibrium locus to rotate downwards to $B P_{1}$. If the region's growth remains at its initial rate where $y$ equals $a$, then the proportion of the region's growth rate given by the distance $a b$ will have to be financed by a growth of largely interregional borrowing by the region. As we noted above, this is not sustainable in the long run, and, consequently, the regional demand equation shifts down to $A_{l} A_{l}$. The region's growth is now given by the point where $y$ equals $b$. Consequently, Brexit has led to a permanently slower growth of the region. The position is more complicated than this because the slower rate of growth of exports will also impact on the growth of other regions that supply intermediate inputs into the 
region's exports. Also the slower growth of exports of the region will lead to the slower growth of imports from other regions, thereby propagating the deflationary forces.

[Figure 1 about here]

The model shows the ineffectiveness of government policy that merely boosts regional aggregate demand. This may shift the $A_{l} A_{l}$ line back to $A_{0} A_{0}$, but, as we have noted, this will have to be financed by increasing interregional capital transfers. An increased sustained growth of the region requires the more difficult problem of increasing the non-price competitiveness of its exports and the search for new overseas markets. In other words, rotating the $\mathrm{BP}_{1}$ line back to $\mathrm{BP}_{0}$.

A fall in the growth of regional exports, and hence, of regional output is likely to lead to a fall in the growth of productivity, through the Verdoorn law, further reducing the region's competiveness price and especially non-price competitiveness (Angeriz et al. 2008).

In the long run, the growth of productivity will be lower unless the region finds other export markets and increases its rate of growth of exports. In a Keynesian world, it is unlikely that wage flexibility will lead to the labour market clearing and so unemployment, or underemployment, will increase. Indeed, the post-Keynesian analysis shows that cutting real wages by cutting regional aggregate demand may make the unemployment situation worse (McCombie, 1985). (See Thirlwall (1980, p.424) for an analysis of the change in regional unemployment in a balance-of-payments constrained growth framework.)

For the UK as a whole, the story is a little different. In this case, trade with the EU is approximately in balance. 
Consequently, it follows that:

$$
y_{B P(U K)}=\frac{\bar{\varepsilon}}{\bar{\pi}} z=y_{B P(U K)}^{\prime}=\frac{\bar{\varepsilon}^{\prime}}{\bar{\pi}^{\prime}} z
$$

An equiproportional decline in the income elasticities of demand for imports and exports will mean that the balance-of-payments growth rate is unaffected by Brexit. However, as we have seen, the level of GDP will decline in the short run from the loss of exports, if there is no compensating increase in domestic production to offset this fall. Hence, the subsequent growth of the UK will be from a lower base. How a region responds to the impact of Brexit is a function of its economic resilience to an economic downturn. There is a large number of studies examining how resilience differs between the regions. (See, for example, Martin et al. 2015; Haldane 2016.) Often output declines with the onset of the recession, but, with recovery, growth typically accelerates for a short period of time until eventually the level of output and productivity are the same as if there had been no recession. There has, however, been a cumulative loss in output over this time. But as we have shown, according to the balance-of-payments constrained model (and HMT, 2016a), Brexit, however, causes a fall in exports that leads to a permanently lower level of output, compared with the baseline. To this extent this approach and HMT come to the same conclusion. Brexit is also likely to reinforce the deep-seated trends of deindustrialisation as exports are predominantly manufacturing goods and increase the North-South divide.

\section{Conclusions}


This paper has considered the possible implications of Brexit for the UK regions. There has been a number of differing forecasts at the national level of the impact of Brexit. Consequently, we began with a critical review of the models behind these forecasts as the impact on the regions depends crucially on the adverse effects of Brexit at the national level.

First, we started by considering the worst case (WTO option) estimates of the influential HMT (2016a) analysis. A key factor in their methodology was to estimate the extra gains in trade the UK had achieved by being a member of the customs union since its accession in 1973 to the European Communities, as the EU then was. It was then assumed that all these gains would be lost after Brexit. This assumes no path dependency or hysteresis and HMT provided no justification for this procedure. An alternative preferable methodology is to look at the disadvantage UK trade with Europe would face in terms of increased tariffs and non-tariff price equivalents resulting from Brexit. The trade loss can then be calculated using import and export demand functions and the estimates of the price and, especially, the income elasticities in demand. While it is beyond the scope of this paper precisely to quantify the results, the estimates of the decline in trade are less than the estimates of HMT.

Secondly, the CBR (Gudgin et al. 2017b) successfully replicated the HMT results of their gravity model. However, they then corrected for a number of misspecification errors in the model. These included the specification that the estimated trade impact in the HMT analysis was for all the EU members, and not just the UK. Correcting for this and other specification errors, they found that the impact on the UK is much smaller than the estimates of HMT (2016a). 
Furthermore, Gudgin et al. (2017a) using the UKMOD Keynesian forecasting model, together with their own assumptions find that the loss of GDP is considerably less that of HMT. However, if they use HMT's more severe assumptions in their model they get similar results.

The Economists for Brexit's positive estimate for the impact Brexit on GDP, relying as it does on the law of one price, are generally considered to be over-optimistic.

We finally analysed the effect of Brexit using the regional balance-of-payments constrained growth model. This is a highly aggregate model (but no more so than the Solow-Swan and other neoclassical growth models). The purpose was to provide a conceptual framework within which to analyse the possible effect of Brexit. It was shown that, in the case where we model the increase in non-tariff barriers as a decrease in the income elasticities of demand, withdrawal from the EU is likely to cause a widening of regional disparities. Those regions which are more heavily dependent on trade with the EU will experience the greatest adverse effects. In the case of the UK as a whole, Brexit will cause a short-run one-off loss in GDP, but not necessarily a decline in its long-term growth rate.

Consequently, the post-Keynesian approach comes to much the same conclusions as the mainstream approach, which is not always the case. However, inevitably, the forecasts effect of Brexit on the UK, and hence its regions, are subject to a great deal of uncertainty.

\section{References}

Angeriz A, McCombie JSL, Roberts M (2008) New estimates of returns to scale and spatial spillovers for the EU regions. International Regional Science Review 31: $62-87$ 
Ashcroft, Lord (2016) How the United Kingdom voted on Thursday... and why. Lord Ashcroft Polls URL: Lordashcroftpolls.com/2016/06/how-the-united-kingdomvoted-and-why/

Bachtler J, Begg I (2016) Cohesion and cohesion policy in the UK: what might Brexit entail? Policy brief prepared for the initiative on the UK in a Changing Europe, based at King's College London and funded by the Economic and Social Research Council (ESRC)

Bell DNF (2017) Regional aid policies after Brexit. Oxford Review of Economic Policy 33: S91-S104

Burrage M (2016) Economical with the truth. A review of HM Treasury analysis: The long-term economic impact of EU membership and the alternatives. Civitas, London

Burrage M (2017) It's quite okay to walk away. Civitas, London

Capello R, Nijkamp P (eds) (2010) Handbook of regional growth and development theories. Edward Elgar, Cheltenham

Centre for Cities (2017) Cities outlook, 2017, URL:

http://www.centreforcities.org/publication/cities-outlook-2017/

Centre for Economic Performance (2016) The UK Treasury analysis of 'the long-term economic impact of EU membership and the Alternatives. CEP Commentary, April

Crafts N (2016) The growth effects of EU membership for the UK: review of the evidence. CAGE and SMF, Global Perspectives Series, Paper 7 
Dhingra S, Huang H, Ottaviano GI, Pessoa JP, Sampson T, Van Reenen J (2017a) The costs and benefits of leaving the EU: Trade effects. CEP Discussion Papers, CEPDP1478. Centre for Economic Performance, London School of Economics and Political Science, London, UK

Dhingra S, Machin S, Overman HG (2017b) The local economic effects of Brexit. CEPBREXIT10, Centre for Economic Performance, London School of Economics and Political Science, London, UK

Dixon R, Thirlwall AP (1975) A model of regional growth-rate differences on Kaldorian lines. Oxford Economic Papers 27: 201-214

Dorling D (2016) Brexit: the decision of a divided country, editorial, BMJ 2016;354:i3697

Dow SC (1986) The capital account and regional balance of payments problems. Urban Studies 23: 173-184

Ebell M (2016) Assessing the impact of trade agreements on trade. National Institute Economic Review 238: R31-R42.

Ebell M, Warren J (2016) The Long-term economic impact of leaving the EU. National Institute Economic Review 236: 121-138

Economists for Brexit (2016a) The economy after Brexit. URL: http://issuu.com/efbkl/docs/economists_for_brexit_-_the_economy

Economists for Brexit (2016b) The Treasury report on Brexit: A Critique. URL: https://issuu.com/efbkl/docs/economists_for_brexit_-_the_treasur 
Emmerson C, Johnson P, Mitchell I, Phillips D (2016) Brexit and the UK's public finances. Institute for Fiscal Studies, Report 116

Felipe, J. McCombie, JSL (2012). Problems with regional production functions and estimates of agglomeration economies: A caveat emptor for regional scientists. Spatial Economic Analysis, 4: 461-484

Felipe J, McCombie JSL (2013) The aggregate production function and the measurement of technical change. "Not even wrong”. Edward Elgar, Cheltenham

Glick R, Rose AK (2015) Currency union and trade. A post-EU mea culpa. NBER Working Paper 21535

Goodwin MJ, Heath O (2016) Brexit vote explained: poverty, low skills and lack of opportunities. Joseph Rowntree Foundation, URL: https://www.jrf.org.uk/report/brexit-vote-explained-poverty-low-skills-and-lackopportunities

Gudgin G, Coutts K, Gibson N (2015) The CBR macro-economic model of the UK economy (UKMOD). WP 472, Centre for Business Research, University of Cambridge

Gudgin G, Coutts K, Gibson N, Buchanan J (2017a) The macro-economic impact of Brexit: using the CBR macro-economic model of the UK economy (UKMOD). WP483 (revised version), Centre for Business Research, University of Cambridge

Gudgin G, Coutts K, Gibson N, Buchanan J (2017b) Defying gravity. A critique of estimates of the economic impact of Brexit, Policy Exchange, London, URL: https://policyexchange.org.uk/wp-content/uploads/2017/06/Defying-Gravity-Acritique-of-estimates-of-the-economic-impact-of-Brexit.pdf 
Haldane A (2016) Whose recovery? Bank of England URL:

http://www.bankofengland.co.uk/publications/Pages/speeches/2016/916.aspx

Her Majesty's Treasury (HMT) (2016a) HM Treasury analysis: the long-term economic impact of EU membership and the alternatives, Her Majesty's Government, CM 9250, April, London

Her Majesty's Treasury (HMT) (2016b) HM Treasury analysis: the immediate economic impact of leaving the EU. Her Majesty’s Government, CM 9292, May, London

Iammarino S, McCann P (2013) Multinationals and economic geography: location, technology and innovation. Edward Elgar Cheltenham

International Monetary Fund (IMF) (2016) United Kingdom; selected issues

Kaldor N (1970) The case for regional policies. Scottish Journal of Political Economy 17: $337-348$

KPMG (2014), The UK automotive industry and the EU, KMPG, URL: https://www.smmt.co.uk/wp-content/uploads/sites/2/SMMT-KPMG-EUReport.pdf

Los B, McCann P, Springford J, Thissen M (2017) The mismatch between local voting and the local economic consequences of Brexit. Regional Studies 51: 786-799

McCann P (2016) The UK regional-national economic problem: geography, globalisation and governance (regions and cities). Routledge, London 
McCombie JSL (1985) Why cutting real wages will not necessarily reduce unemployment-Keynes and the "postulates of the classical economics". Journal of Post Keynesian Economics 8: 233-248

McCombie JSL (1988), A synoptic view of regional growth and unemployment: IIThe post-Keynesian theory. Urban Studies 25: 399-417

McCombie JSL (1993) Economic growth, trade interlinkages, and the balance-ofpayments constraint. Journal of Post Keynesian Economics 15: 471-505

McCombie JSL, Pugno M, Soro B (eds) (2002) Productivity growth and economic performance: essays on Verdoorn's law. Palgrave Macmilllan, Basingstoke

McCombie JSL, Thirlwall AP (1994) Economic growth and the balance-of-payments constraint. Macmillan, Basingstoke

Marshall A (1890) Principles of economics: an introductory volume (8th eds) Macmillan, London

Martin R, Sunley PJ (2015) On the notion of regional economic resilience: conceptualization and explanation. Journal of Economic Geography 15: 1-42

Minford P, Gupta S, Le VPM, Mahambare V, Xu Y (2015) Should Britain leave the EU?: an economic analysis of a troubled relationship. Edward Elgar, Cheltenham

National Audit Office (2017) HM Treasury's economic analysis in the lead-up to the referendum on European Union membership, National Audit Office Report, London

Norton W (2017) Mitigating the impact of tariffs on UK-EU trade. Europe Debate no.6 Civitas, London 
North DC (1955) Location theory and regional economic growth. Journal of Political Economy 63: 243-258

Office for Budget Responsibility (OBR) (2013) The macroeconomic model, Briefing Paper No. 5, URL: http://budgetresponsibility.org.uk/

Office for Budget Responsibility (OBR) (2017) Economic and fiscal outlook, Cm 9419, URL: http://budgetresponsibility.org.uk/efo/economic-fiscal-outlook-march-2017/

Organisation for Economic Co-operation and Development (OECD) (Kierzenkowski R, Pain N, Rusticelli E, Zwart S) (2016) The economic consequences of Brexit: a taxing decision, OECD Economic Policy Papers, No 16, OECD, Paris

Ottaviano G, Pessoa JP, Sampson T, Van Reenen J (2014) The costs and benefits of leaving the EU, Center for Financial Studies, Working Paper Series, No.472.

Oxford Economics (2008) Regional winners and losers in public finances. Economic Outlook, 32: 5-15

Protts J (2016) UK-EU trade and jobs linked to exports. Briefing note, September, Civitas, London

$P w C$ (2016) Leaving the EU: Implications for the UK economy. March, $P w C$,

URL: https://www.pwc.co.uk/services/economics-policy/insights/implications-of-an-euexit-for-the-uk-economy.html

Resolution Foundation (2016), (Bell, T.) The referendum, living standards and inequality, URL: http://www.resolutionfoundation.org/media/blog/thereferendum-living-standards-and-inequality/

Rowthorn RE (2010) Combined and uneven development: reflections on the NorthSouth divide. Spatial Economic Analysis 5: 363-388 
Sampson T, Dhingra S, Ottaviano G, Van Reenen J (2016) Economists for Brexit: a critique, CEP Brexit Analysis No. 6, Centre for Economic Performance, London School of Economics, London

Springford J (2015) Disunited kingdom: Why 'Brexit' endangers Britain's poorer regions, Centre for European Reform, URL:

http://www.cer.org.uk/publications/archive/policy-brief/2015/disunited-kingdom-why$\%$ E2\%80\%98brexit\%E2\%80\%99-endangers-britain\%E2\%80\%99s-poorer-reg

Sheffield Political Economy Research Institute (SPERI) (2016) UK regions, the European Union and manufacturing exports, SPERI British Political Economy Brief No. 24, University of Sheffield, Sheffield

Swales K (2016) Understanding the leave vote. NatCen Social Research, London

Slater A (2016) Will Brexit Speed a Seismic Shift in UK Trade Patterns? Economic Outlook 40: 13-17

The Economist (2012) Making the break. URL: http://www.economist.com/news/briefing/21567914-how-britain-could-fall-outeuropean-union-and-what-it-would-mean-making-break

The UK in a Changing Europe (2017) The cost of no deal URL: http://ukandeu.ac.uk/research-papers/cost-of-no-deal/

The World Trade Organisation (2012) Trade and public policies: A closer look at nontariff measures in the 21 st century. The world trade report, 2012, URL: https://www.wto.org/english/res_e/booksp_e/anrep.../world_trade_report12_e.pdf

Thirlwall, AP (1980) Regional problems are 'balance-of-payments' problems. Regional Studies 14: 419-425 
Thirlwall AP, Dixon RJ (1979) A model of export-led growth with a balance of payments constraint. In: Bowers JK (eds) Inflation, development and integration. Essays in honour of AJ Brown. Leeds University Press, Leeds

Tiebout CM (1956) Exports and regional economic growth. Journal of Political Economy 64: 160-164

Winters A (2017) Will eliminating UK tariffs boost UK GDP by 4 percent? Even 'Economists for Free Trade' don't believe it, URL: https://blogs.sussex.ac.uk/uktpo/2017/04/19/will-eliminating-uk-tariffs-boost-ukgdp-by-4-percent/

Verdoorn PJ (1949) Fattori che regolano lo sviluppo produttitività del lavoro. L'Industria 1: 3-10 (a translation is reprinted as chapter 2 in McCombie et al. 2002) 


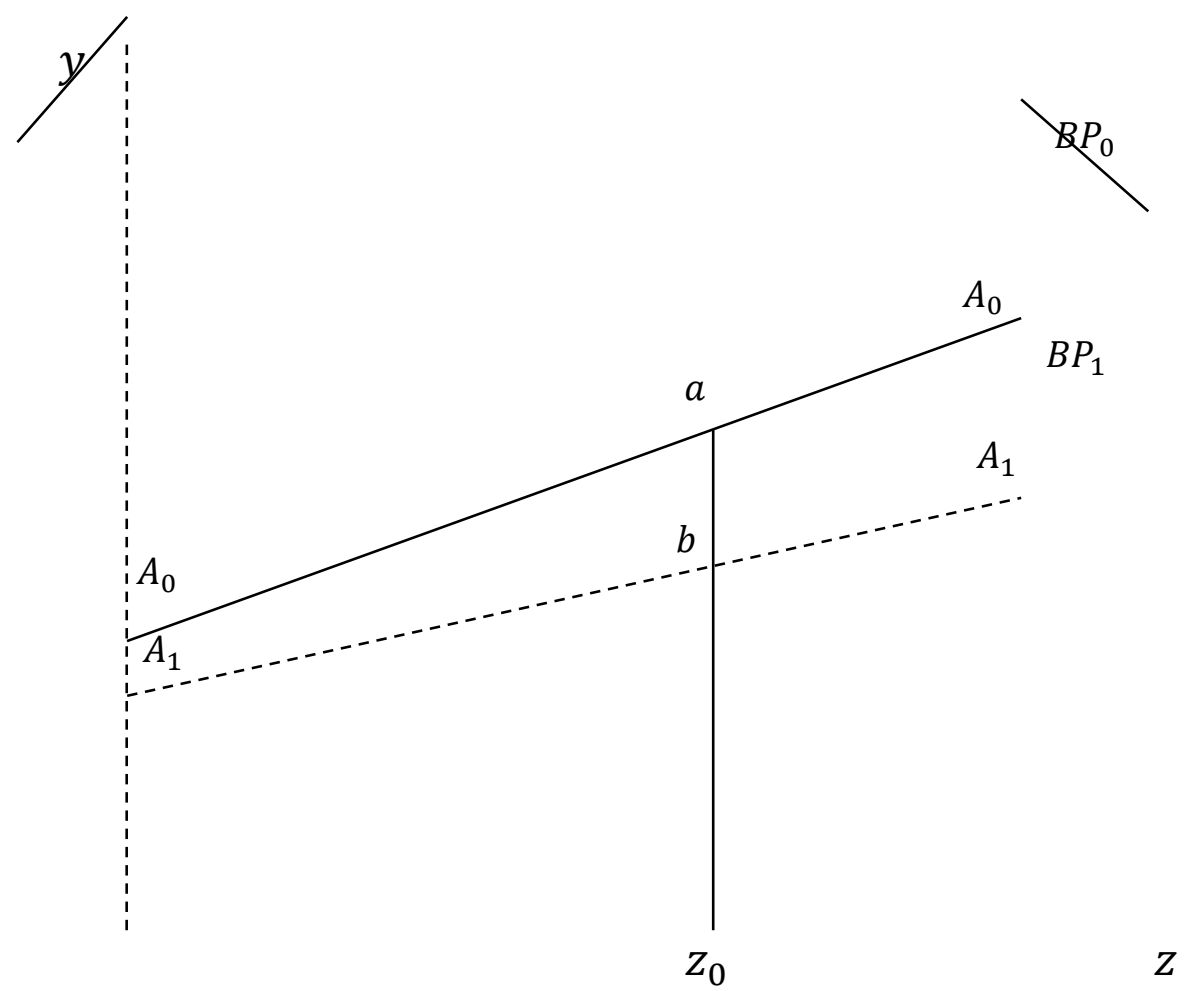

Figure1. The effect of Brexit region's balance-of-payments constrained growth rate 